\title{
Pathogenic Specialization and Pathotype Distribution of Puccinia hordei in Australia, 1992 to 2001
}

\author{
R. F. Park, University of Sydney, Plant Breeding Institute Cobbitty, Private Mail Bag 11, Camden, NSW, 2570, \\ Australia
}

\begin{abstract}
Park, R. F. 2003. Pathogenic specialization and pathotype distribution of Puccinia hordei in Australia, 1992 to 2001. Plant Dis. 87:1311-1316.

Annual surveys of pathogenic variability in the leaf rust pathogen of barley, Puccinia hordei, from 1992 to 2001 revealed a significant shift in the composition of populations across Australia. Virulence for the resistance gene $R p h 12$, first detected in a single pathotype, $4610 \mathrm{P}+$, in Tasmania in 1991, was subsequently detected in 1993 in South Australia, Victoria, and southern New South Wales. By the end of 2001, eight pathotypes with virulence for Rph12 had been isolated, and virulence for this gene was present in all Australian barley growing regions. Virulence was not detected for the resistance genes $R p h 3, R p h 7, R p h 11$, or $R p h 14$. The distribution and spread of the pathotypes detected, their possible origins, pathogenicity on several uncharacterized seedling resistance sources, and implications for resistance breeding are discussed.
\end{abstract}

Additional keywords: barley, Hordeum vulgare, leaf rust

Studies of pathogenic variability in Puccinia graminis f. sp. tritici were the first to demonstrate the existence of physiologic races in a rust fungus (14). Isolates of the pathogen were found that differed in ability to infect a set of wheat genotypes, known as differentials; and those isolates with the same pathogenic attributes on the set of differentials were referred to as a physiologic race. Such races, also referred to as strains or pathotypes, are now known to exist in all cereal rust fungi, and monitoring their occurrence and distribution in annual pathogenicity surveys is an important part of many efforts to develop cultivars with rust resistance.

The leaf rust disease of barley is caused by Puccinia hordei G. Otth. This pathogen occurs in all barley growing regions of Australia and has reached epidemic levels and caused yield reductions in some regions since at least 1927 (17). Estimates of yield losses due to the disease under Australian conditions were about $30 \%$ in a susceptible spring barley cultivar (5). A retrospective study of the pathogenicities of isolates collected periodically from 1966 to 1990 provided an overview of variability in $P$. hordei in Australia (1). Eleven pathotypes were detected $(20 \mathrm{P}+, 200 \mathrm{P}+, 201 \mathrm{P}+$, $210 \mathrm{P}+, 211 \mathrm{P}+, 220 \mathrm{P}+, 230 \mathrm{P}+, 243 \mathrm{P}+$, $243 \mathrm{P}-, 253 \mathrm{P}-$, and $4610 \mathrm{P}+$ ) during this

Corresponding author: R. F. Park

E-mail: robertp@camden.usyd.edu.au

Accepted for publication 29 May 2003.

Publication no. D-2003-0825-01R

(C) 2003 The American Phytopathological Society period, and there was evidence of an increase in the frequency of virulence for the resistance gene Rph4 in Queensland during the 1980 s, possibly as a consequence of the widespread use of the cultivar Grimmett, which possesses this gene (1).

Annual pathogenicity surveys of $P$. hordei in Australia began in 1992. This paper presents data obtained for surveys over the 10-year period 1992 to 2001, providing information on the frequency of virulence for resistance genes present in barley cultivars and on the migration of pathotypes throughout the Australian region. It also includes the results of greenhouse studies conducted to examine possible relationships between some of the pathotypes detected, to try to understand their most likely origin.

\section{MATERIALS AND METHODS}

Previous long-term studies of pathogenic variability in $P$. graminis f. sp. tritici identified four epidemiological regions within Australia, differentiated on the basis of climate and wheat cultivar deployment (21; Fig. 1). Region 1, comprising northern New South Wales (nNSW) and Queensland (Qld), is characterized by a summerdominant rainfall pattern, which increases the likelihood for cereal rusts to oversummer (8). Region 2, southern New South Wales (sNSW), Victoria (Vic), and Tasmania (Tas), is characterized by a winter-dominant rainfall pattern. Region 3, South Australia (SA), while climatically similar to region 2, was regarded as discrete on the basis of the different wheat cultivars grown there. Region 4, Western Australia (WA), is isolated from the eastern Australian cereal growing regions by more than $1,000 \mathrm{~km}$ of arid land. These regions were adopted for the current study because of climatic differences (regions 1 and 2), geographic separation (region 4), and also because of the presence of the alternate host of $P$. hordei, Ornithogalum umbellatum, in region 3 (16).

The survey period for each year was from 1 April until 31 March the following year.

Sample collection and storage. Samples of leaf rust were collected from barley crops, experimental plots, or self-sown barley plants by various co-operators, and forwarded to the Plant Breeding Institute Cobbitty (PBIC) by post. Additional samples were collected by PBIC staff during regular surveys that involved random crop inspections every 20 to $30 \mathrm{~km}$ along predetermined routes. Rust samples were stored in paper envelopes and dried in a dehumidified cool room at 10 to $12^{\circ} \mathrm{C}, 12 \%$ relative humidity $(\mathrm{RH})$. Rust isolates maintained good viability under these conditions for up to 4 weeks.

Differential genotypes and pathotype nomenclature. Twelve differential genotypes were used to assign an octal pathotype designation to each isolate (6). The 12 differentials and corresponding octal values are given in Table 1. Octal designations were determined by adding values that corresponded to each differential to which a given isolate was virulent. For example, pathotype 4610 was virulent for $R p h 4, R p h 8$, Rph9, and Rph12 (10+200+400+4000). The suffix $\mathrm{P}+$ or $\mathrm{P}-$ was added to each octal designation to indicate virulence or avirulence, respectively, for the resistance gene Rph19, present in the differential cultivar Prior $(1,13)$. An additional 10 differentials were included in tests, each with a gene combination or an uncharacterized resistance. The differentials Berg, Reka I, Ricardo, and Quinn were used in all years, whereas Cantala, PI 366444, and Q21861 were used from 1997 to 2001 only, and PI 531849, PI 584760, and Gatami were used from 1999 to 2001 only. The susceptible cultivar Gus was also included in each differential set as a control. The differential genotypes were sown in clumps of 10 to 12 seedlings, with either four or five clumps per 90-mm-diameter pot and five pots per differential set.

Inoculation. Samples that lacked sufficient inoculum were first increased on the susceptible barley cultivar Gus by transferring inoculum from dried leaf samples to 
primary leaves with a spatula and incubating for 2 days in a chamber at $100 \% \mathrm{RH}$ and 20 to $25^{\circ} \mathrm{C}$. Samples with an adequate amount of inoculum were cut into short segments (ca. $1 \mathrm{~cm}$ in length) and agitated in a light mineral oil (Pegasol 3440 Special, Mobil Oil, Sydney, NSW) to produce a spore suspension that was applied directly to differential sets with an atomizer. Inoculated differential sets were incubated in an insulated misting room at ambient temperatures in darkness for 18 to $24 \mathrm{~h}$. one pathotype, and if it was not possible to identify the pathotypes present accurately, single-pustule isolates were established from particular differential genotypes using the susceptible cultivar Gus. Usually, one inoculation cycle on Gus was sufficient to generate the inoculum needed to inoculate a differential set. The pathogenicities of all pathotypes detected were confirmed in repeated tests.

Comparative greenhouse tests of pathotypes virulent for Rph12. An experiment was conducted using seedlings (8- to 10-day-old; Table 1) to compare the pathogenicity of representative isolates of eight pathotypes detected that were virulent for Rph12 on all barley differential genotypes. This experiment allowed comparisons to be made under uniform conditions, and also allowed testing of all differentials including those not used for the entire 10-year period. The methods used for plant growth, inoculation, and postWhere accessions comprised more than

inoculation incubation were the same as those used in conducting routine pathogenicity tests. The experiment was repeated to ensure reproducibility of the results obtained.

Data collection. Inoculated differential sets were maintained in a greenhouse microclimate compartment with temperature controlled within the range 18 to $25^{\circ} \mathrm{C}$, and with natural lighting. Results were recorded at 11 to 12 days postinoculation using a 0 to 4 infection type (IT) scale similar to that used in studies of the wheat leaf rust pathogen, Puccinia triticina (10). The infection types were: $0=$ no visible symptoms, ; = hypersensitive flecks, $1=$ minute uredinia surrounded by mainly necrotic tissue, 2 = small to medium sized uredinia surrounded by chlorotic and/or necrotic tissue, 3 = medium to large uredinia with or without surrounding chlorosis, 4 = large uredinia without chlorosis, $\mathrm{X}=$ mesothetic, heterogeneous infection types similarly distributed over the leaf. The letters " $\mathrm{C}$ " and " $\mathrm{N}$ " were included to indicate greater than normal chlorosis or necrosis, respectively, and the symbols "_," or "+" to indicate lower or higher infection types, respectively, than normal. Infection types of $3+$ or higher were considered to be compatible (i.e., virulent pathogen/susceptible host).

\section{RESULTS}

Viable isolates were established from a total of 260 samples over the 10-year pe-

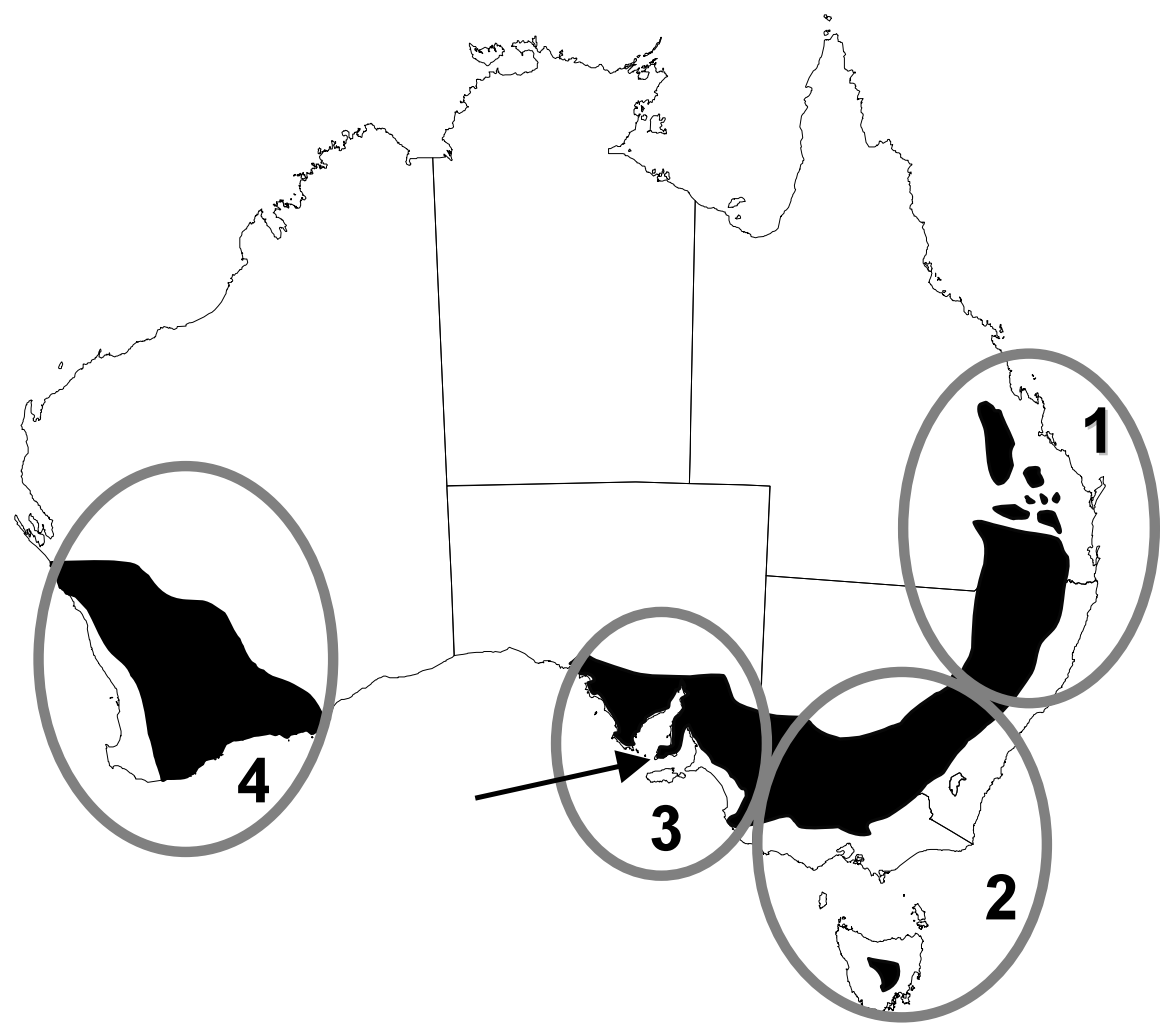

Fig. 1. Cereal producing areas of Australia and the four regions delineated on the basis of climate and epidemiology of Puccinia hordei. Arrow indicates location of Yorke Peninsula. Region 1, Queensland and northern New South Wales; region 2, southern New South Wales, Victoria, and Tasmania; region 3, South Australia; region 4, Western Australia. riod, and 432 individual identifications of pathotypes (pts) were made (Table 2). Twenty-two pathotypes were identified using the standard 12 differentials plus the supplementary differentials. Most samples originated from region 2 (Table 2). Very dry conditions were experienced in region 1 during 1991 to 1994,1997 , and in 2000. Consequently, $P$. hordei was not common in this region during 1992 to 2001, and only 22 samples were received.

Frequency and distribution of pathotypes and virulence factors. Virulence was not detected for the resistance genes $R p h 3, R p h 7, R p h 11$, or Rph14. All pathotypes identified were either virulent for Rph 9 and Rph12 or avirulent for both genes, and similarly, all pathotypes were either virulent or avirulent for $R p h 2$ and $R p h Q$. Consequently, virulence frequencies for Rph 9 and Rph12, and for Rph2 and $R p h Q$, were the same over the survey period (Table 3 ). The frequency of virulence for the genes Rph 9 and Rph12 increased in all regions during the 10 -year period (Table 3). All pathotypes virulent for $R p h 9$ and Rph12 were virulent for $R p h 4$, and most were also virulent for $R p h 10$ and RphPI366444, and so virulence for these genes also followed a similar pattern to virulence for Rph9 and Rph12 (Table 3). Virulence for RphCantala and for RphGatami declined following the detection of pathotypes $5610 \mathrm{P}+$ and $5453 \mathrm{P}-$, avirulent for each gene, respectively; and virulence for $R p h 13$ increased following the detection of pathotypes $4652 \mathrm{P}+$ and $4653 \mathrm{P}+$, virulent for this gene. Virulence on the remaining seven resistance genes did not show any distinct trends and was either generally high (Rph6, Rph8, and Rph19) or fluctuated (Rph1, Rph2, Rph5, and RphQ) (Table 3).

Virulence for Rph12 was detected for the first time in Australia in a single sample of leaf rust collected from the cultivar Franklin in Tas in 1990, and the pathotype was identified as pt $4610 \mathrm{P}+$ (1). This pathotype was again isolated from Tas in most years up to 2001. It was also identified in samples collected in November 1993 from SA, Vic, and sNSW; and in 1999 it was detected in samples collected from nNSW and Qld (Tables 4 to 7). A further seven pathotypes virulent for Rph12 were identified after the initial detection of pt $4610 \mathrm{P}+$. Pt 5610P+ was first detected near Ravensthorpe, WA, from samples collected in August 1997. This pathotype was subsequently detected in eastern Australia in the 1998 survey, first from SA (Bute, October) and then from Vic (Inverleigh, December), and then in sNSW and Qld in the 1999 survey (Tables 4 to 7$)$. In WA, a second pathotype with virulence for Rph12, pt 5453P-, was detected in 2001 (Table 7). Pt 5452P+ was detected for the first time in a sample collected from SA in late September 1999 (Table 6), and subsequently in samples collected from Vic and Tas in mid-October 
(Table 5). Pt 4653P+, with added virulence for Rph13, was first detected in a sample collected from Tas in October 1999 (Table 5). This pathotype was subsequently de- tected in samples collected from Vic and sNSW in November 1999, and then from region 1 in 2000 and region 3 in 2000 and 2001. A second pathotype with added viru- lence for Rph13, 4652P+, was first detected in Tas in December 2001 (Table 5).

Fourteen pathotypes avirulent for Rph12 were detected, seven of which had

Table 1. Response of differential barley genotypes to selected Australian isolates of Puccinia hordei ${ }^{\mathrm{a}}$

\begin{tabular}{|c|c|c|c|c|c|c|c|c|c|c|c|}
\hline \multirow[b]{2}{*}{$\begin{array}{l}\text { Host } \\
\text { genotype }^{b}\end{array}$} & \multirow[b]{2}{*}{$\begin{array}{l}\text { Resistance } \\
\text { gene }\end{array}$} & \multirow[b]{2}{*}{$\begin{array}{l}\text { Octal } \\
\text { value }\end{array}$} & \multicolumn{9}{|c|}{ Pathotype [accession number] } \\
\hline & & & $\begin{array}{l}\text { 210P+ } \\
{[900041]}\end{array}$ & $\begin{array}{l}4610 \mathrm{P}+ \\
{[900380]}\end{array}$ & $\begin{array}{l}\text { 4652P+ } \\
{[010187]}\end{array}$ & $\begin{array}{l}\text { 4653P+ } \\
{[990492]}\end{array}$ & $\begin{array}{l}\text { 5452P+ } \\
{[010189]}\end{array}$ & $\begin{array}{l}\text { 5453P- } \\
{[010037]}\end{array}$ & $\begin{array}{l}\text { 5610P+ } \\
{[970073]}\end{array}$ & $\begin{array}{l}5653 P+ \\
{[010116]}\end{array}$ & $\begin{array}{l}\text { 5673P+ } \\
{[010187]}\end{array}$ \\
\hline Sudan & Rphl & 1 & $; 1+\mathrm{CN}$ & $; 12 \mathrm{~N}$ & $12 \mathrm{~N}$ & $3+$ & $; 12 \mathrm{~N}$ & $3+$ & $; 1+\mathrm{CN}$ & $3+\mathrm{N}$ & $3+$ \\
\hline Peruvian & Rph2 & 2 & $; 12-\mathrm{CN}$ & ;12-CN & $3+$ & $X++3$ & $3+$ & $3+$ & $; 12-\mathrm{N}$ & $3+$ & $33+$ \\
\hline Estate & Rph3 & 4 & $; 1=$ & $; 1=$ & 0 & $; 1-$ & ; & $; 1=$ & $; 1-$ & ;- & 0 \\
\hline Gold & Rph4 & 10 & $3+$ & $3+$ & $3+$ & $3+$ & $3+$ & $3+$ & $3+$ & $3+$ & $3+$ \\
\hline Magnif 104 & Rph5 & 20 & $; 1-\mathrm{N}$ & ;N & 0 & ;N & ;N & ;N & ;N & $; 1 \mathrm{~N}$ & $3+$ \\
\hline Bolivia & $\operatorname{Rph} 2+6$ & 40 & $; 12-\mathrm{CN}$ & $; 1 \mathrm{~N}$ & $3+$ & $3+$ & $3+$ & $3+$ & $; 1+\mathrm{N}$ & $3+$ & $3+$ \\
\hline Cebada Capa & Rph7 & 100 & 0 & 0 & 0 & $;-\mathrm{N}$ & $;-\mathrm{N}$ & $;++\mathrm{N}$ & $;-\mathrm{N}$ & 0 & $;-\mathrm{N}$ \\
\hline Egypt 4 & Rph 8 & 200 & $3+$ & $3+$ & $3+$ & $3+$ & $2+\mathrm{CN}$ & $2+\mathrm{CN}$ & $3+$ & $3+$ & $3+$ \\
\hline Abyssinian & Rph 9 & 400 & $; 12-\mathrm{C}$ & $3+$ & $33+$ & $3+$ & $3+$ & $3+$ & $3+$ & $3+$ & $3+$ \\
\hline Clipper BC8 & $R p h 10^{c}$ & 1000 & $; 1+\mathrm{C}$ & $12-\mathrm{C}$ & $33-$ & $12+\mathrm{C}$ & $3+$ & $3+$ & $3+$ & $3+$ & $3+$ \\
\hline Clipper BC67 & $\operatorname{Rph} 11^{\mathrm{c}}$ & 2000 & $12-\mathrm{CN}$ & $12-\mathrm{CN}$ & $33-$ & $12-\mathrm{C}$ & $12+C$ & $12+\mathrm{C}$ & $12-\mathrm{CN}$ & $12+\mathrm{C}$ & $12+$ \\
\hline Triumph & Rph12 & 4000 & $; 1+\mathrm{N}$ & $3+$ & $3+$ & $3+$ & $3+$ & $3+$ & $3+$ & $3+$ & $3+$ \\
\hline Gus & None & & $3+$ & $3+$ & $3+$ & $3+$ & $3+$ & $3+$ & $3+$ & $3+$ & $3+$ \\
\hline Berg & Rphl & & ;N & ;N & ;N & $3+$ & $; 1 \mathrm{~N}$ & $3+$ & ;N & $3+$ & $3+$ \\
\hline Reka I & $R p h 2+R p h 19$ & & $; 12 \mathrm{~N}$ & $; 12 \mathrm{~N}$ & $3+$ & $3+$ & $3+$ & $3 \mathrm{CN}$ & $; 1+\mathrm{N}$ & $3+$ & $3+$ \\
\hline Ricardo & $R p h 2+?$ & & $; 12-\mathrm{N}$ & $; 1++\mathrm{CN}$ & 3 & $2++\mathrm{C}$ & $12+\mathrm{C}$ & $33+$ & $; 1++\mathrm{N}$ & $3-\mathrm{C}$ & $22-\mathrm{C}$ \\
\hline Quinn & $R p h 2+R p h 5$ & & ;N & ;N & ;CN & ;N & ;N & ;N & ;N & $; 1 \mathrm{~N}$ & $3+$ \\
\hline PI 531849 & $R p h 13^{\mathrm{d}}$ & & ;N & ;N & $3+$ & $3+$ & ;N & ;N & ;N & ;N & $; 1 \mathrm{~N}$ \\
\hline PI 584760 & $R p h 14^{\mathrm{d}}$ & & $12 \mathrm{CN}$ & $12+C$ & $; 12 \mathrm{~N}$ & ;12-C & $; 1 \mathrm{~N}$ & $; 1+\mathrm{N}$ & $12+C$ & $; 12-\mathrm{N}$ & $12-\mathrm{N}$ \\
\hline Prior & Rph19 & $\mathrm{P}$ & $3+$ & $3+$ & $3+$ & $3+$ & $3+$ & $12+\mathrm{CN}$ & $3+$ & $3+$ & $3+$ \\
\hline Q21861 & $R p h Q^{\mathrm{e}}$ & & $; 1+\mathrm{N}$ & $; 1 \mathrm{~N}$ & $3+$ & $3+$ & $3+$ & $3+$ & $; 1-\mathrm{N}$ & $3+$ & $3+$ \\
\hline Cantala & RphCantala & & $3+$ & $3+$ & $3+$ & $3+$ & $3+$ & $2++3$ & $3+$ & $3+$ & $3+$ \\
\hline PI 366444 & RphPI366444" & & $2+\mathrm{CN}$ & $2+\mathrm{CN}$ & $3+$ & $3+$ & $3+$ & $3+$ & $3+$ & $3+$ & $3+$ \\
\hline Gatami & RphGatami ${ }^{\mathrm{d}}$ & & $3+$ & $3+$ & $33+$ & $3+$ & $3+$ & $3+$ & ;N & $3+$ & $3+$ \\
\hline \multicolumn{12}{|c|}{$\begin{array}{l}\text { Infection types: } 0=\text { no visible symptoms, } ;=\text { hypersensitive flecks, } 1=\text { minute uredinia surrounded by mainly necrotic tissue, } 2=\text { small to medium sized } \\
\text { uredinia surrounded by chlorotic and/or necrotic tissue, } 3=\text { medium to large uredinia with or without surrounding chlorosis, } 4=\text { large uredinia without } \\
\text { chlorosis, } X=\text { mesothetic, heterogeneous infection types similarly distributed over the leaf. C and } \mathrm{N} \text { indicate greater than normal chlorosis or necrosis, } \\
\text { respectively. - and + to indicate lower or higher infection types, respectively, than normal. }\end{array}$} \\
\hline \multicolumn{12}{|c|}{$\begin{array}{l}\text { b The first } 12 \text { genotypes plus cultivar Prior comprise the standard differential set used to assign octal pathotype designations to isolates. The } 11 \text { additional } \\
\text { genotypes are supplementary host lines that include a susceptible control (Gus) and lines carrying either single uncharacterized resistance genes or gene } \\
\text { combinations. }\end{array}$} \\
\hline \multicolumn{12}{|c|}{ c Tests were repeated on adult plants to confirm pathogenicities (data not shown). } \\
\hline \multicolumn{5}{|c|}{ d Added in 1999.} & & & & & & & \\
\hline
\end{tabular}

Table 2. Frequency of pathotypes of Puccinia hordei identified in Australia from 1992 to 2001, classified by state or region ${ }^{\mathrm{a}}$

\begin{tabular}{|c|c|c|c|c|c|c|c|c|}
\hline \multirow[b]{3}{*}{ Pathotype } & \multicolumn{7}{|c|}{ State/region } & \multirow[b]{3}{*}{ Total } \\
\hline & \multicolumn{2}{|c|}{ Region 1} & \multicolumn{3}{|c|}{ Region 2} & \multirow{2}{*}{$\begin{array}{c}\text { Region } 3 \\
\text { SA }\end{array}$} & \multirow{2}{*}{$\begin{array}{c}\text { Region } 4 \\
\text { WA }\end{array}$} & \\
\hline & Qld & NSW (north) & NSW (south) & Vic & Tas & & & \\
\hline $200 \mathrm{P}+\mathrm{b}$ & 0 & 3 & 10 & 3 & 0 & 7 & 1 & 24 \\
\hline $201 \mathrm{P}+\mathrm{b}$ & 0 & 0 & 1 & 0 & 0 & 0 & 0 & 1 \\
\hline $210 \mathrm{P}+\mathrm{b}$ & 2 & 1 & 4 & 3 & 1 & 10 & 0 & 21 \\
\hline $211 \mathrm{P}+\mathrm{b}$ & 0 & 0 & 0 & 0 & 0 & 2 & 0 & 2 \\
\hline $220 \mathrm{P}+\mathrm{b}$ & 1 & 1 & 20 & 10 & 3 & 28 & 1 & 64 \\
\hline $222 \mathrm{P}+$ & 0 & 0 & 0 & 0 & 0 & 4 & 0 & 4 \\
\hline $230 \mathrm{P}+\mathrm{b}$ & 0 & 1 & 0 & 0 & 0 & 5 & 0 & 6 \\
\hline $232 \mathrm{P}+$ & 0 & 0 & 5 & 1 & 1 & 10 & 0 & 17 \\
\hline $242 \mathrm{P}+$ & 0 & 0 & 0 & 1 & 0 & 0 & 0 & 1 \\
\hline 243P_b & 1 & 0 & 0 & 0 & 0 & 0 & 0 & 1 \\
\hline $243 \mathrm{P}+\mathrm{b}$ & 3 & 2 & 12 & 6 & 0 & 7 & 1 & 31 \\
\hline $253 \mathrm{P}+$ & 0 & 0 & 1 & 0 & 0 & 1 & 0 & 2 \\
\hline $262 \mathrm{P}+$ & 0 & 0 & 0 & 0 & 0 & 1 & 0 & 1 \\
\hline $272 \mathrm{P}+$ & 0 & 0 & 1 & 0 & 0 & 1 & 0 & 2 \\
\hline $4610 \mathrm{P}+\mathrm{b}$ & 11 & 2 & 32 & 14 & 10 & 27 & 0 & 96 \\
\hline $4652 \mathrm{P}+(+R p h 13)$ & 0 & 0 & 0 & 0 & 1 & 0 & 0 & 1 \\
\hline $4653 \mathrm{P}+(+R p h 13)$ & 1 & 0 & 3 & 6 & 15 & 2 & 0 & 27 \\
\hline $5452 \mathrm{P}+$ & 0 & 0 & 8 & 14 & 21 & 15 & 0 & 58 \\
\hline $5453 \mathrm{P}-$ & 0 & 0 & 0 & 0 & 0 & 0 & 9 & 9 \\
\hline $5610 \mathrm{P}+$ & 3 & 1 & 6 & 5 & 5 & 7 & 29 & 56 \\
\hline $5653 \mathrm{P}+$ & 0 & 0 & 0 & 4 & 0 & 0 & 0 & 4 \\
\hline $5673 \mathrm{P}+$ & 0 & 0 & 0 & 2 & 2 & 0 & 0 & 4 \\
\hline Total & 22 & 11 & 103 & 69 & 59 & 127 & 41 & 432 \\
\hline
\end{tabular}

a Qld, Queensland; NSW, New South Wales; Vic, Victoria; Tas, Tasmania; SA, South Australia; WA, Western Australia.

${ }^{b}$ Detected in a previous study, 1966 to 1990 , by Cotterill et al. (1). 
been detected previously in Australia (200P+, 201P+, 210P+, 220P+, 230P+, $243 \mathrm{P}-$, and $243 \mathrm{P}+$ ), and seven of which had not $(211 \mathrm{P}+, 222 \mathrm{P}+, 232 \mathrm{P}+, 242 \mathrm{P}+$, 253P+, 262P+, and 272P+). Most of these pathotypes were isolated infrequently, and three of the five that were most common (pts 200P+, 210P+, and 243P+) were also common during 1966 to 1990 (1).
Comparative greenhouse tests of pathotypes virulent for Rph12. Pathotype $4610 \mathrm{P}+$ was pathogenically similar to $\mathrm{pt}$ $210 \mathrm{P}+$ and may have been derived from it by acquiring virulence for the genes $R p h 9$ and Rph12 (Table 1). The seven Rph12 virulent pathotypes that were detected after the initial detection of $\mathrm{pt} 4610 \mathrm{P}+(4652 \mathrm{P}+$ [+Rph13], 4653P+ [+Rph13], 5452P+, $5453 \mathrm{P}-, 5610 \mathrm{P}+, 5653 \mathrm{P}+$, and $5673 \mathrm{P}+$ ) were clearly not simple mutational derivatives from it (Table 1). Like pt 4610P+, all were virulent for $R p h 9$ and $R p h 12$, features not detected in Australia prior to the detection of pt $4610 \mathrm{P}+$. All seven pathotypes were also virulent for an uncharacterized resistance in the barley line PI366444 (Table 1), a characteristic that was rare in other Australian pathotypes of $P$. hordei (R. F. Park, unpublished data).

Table 3. Percentage of isolates of Puccinia horde $i$ with virulence for individual resistance genes, Australia, 1992 to 2001

\begin{tabular}{|c|c|c|c|c|c|c|c|c|c|c|}
\hline \multirow[b]{2}{*}{ Resistance gene $^{a}$} & \multicolumn{10}{|c|}{ Virulence frequency $(\%)$} \\
\hline & 1992 & 1993 & 1994 & 1995 & 1996 & 1997 & 1998 & 1999 & 2000 & 2001 \\
\hline Rph1 & 23.5 & 23.3 & 9.1 & 16.7 & 17.2 & 0 & 5.3 & 15.8 & 14.8 & 32.5 \\
\hline $\operatorname{Rph} 2$ & 58.8 & 33.7 & 18.2 & 16.7 & 20.7 & 0 & 7.0 & 25.0 & 55.7 & 72.7 \\
\hline Rph4 & 52.9 & 54.7 & 63.6 & 83.3 & 44.8 & 83.3 & 47.4 & 89.5 & 85.2 & 87.0 \\
\hline $\operatorname{Rph} 5$ & 58.8 & 30.2 & 27.3 & 0 & 31.0 & 16.7 & 36.8 & 7.9 & 14.8 & 16.9 \\
\hline Rph6 & 17.6 & 41.9 & 54.5 & 91.7 & 55.2 & 83.3 & 49.1 & 88.2 & 85.2 & 87.0 \\
\hline $\operatorname{Rph} 8$ & 100 & 100 & 100 & 100 & 100 & 100 & 100 & 92.1 & 62.3 & 50.6 \\
\hline $\operatorname{Rph} 9$ & 0 & 19.8 & 36.4 & 75.0 & 37.9 & 83.3 & 45.6 & 85.5 & 85.2 & 85.7 \\
\hline Rph10 & 0 & 0 & 0 & 0 & 0 & 33.3 & 17.5 & 50.0 & 49.2 & 66.2 \\
\hline Rph12 & 0 & 19.8 & 36.4 & 75.0 & 37.9 & 83.3 & 45.6 & 85.5 & 85.2 & 85.7 \\
\hline Rph13 & $\ldots{ }^{b}$ & $\ldots$ & $\ldots$ & $\ldots$ & $\ldots$ & $\ldots$ & $\ldots$ & 14.5 & 14.8 & 10.4 \\
\hline Rph19 & 94.1 & 100 & 100 & 100 & 100 & 100 & 100 & 100 & 100 & 88.3 \\
\hline RphCantala & $\ldots$ & $\ldots$ & $\ldots$ & $\ldots$ & $\ldots$ & 100 & 100 & 100 & 100 & 88.3 \\
\hline RphPI366444 & $\ldots$ & $\ldots$ & $\ldots$ & $\ldots$ & $\ldots$ & 33.3 & 17.5 & 64.5 & 63.9 & 76.6 \\
\hline$R p h Q$ & $\ldots$ & $\ldots$ & $\ldots$ & $\ldots$ & $\ldots$ & 0 & 7.0 & 25.0 & 55.7 & 72.7 \\
\hline RphGatami & $\ldots$ & $\ldots$ & $\ldots$ & $\ldots$ & $\ldots$ & $\ldots$ & $\ldots$ & 57.9 & 88.5 & 93.5 \\
\hline
\end{tabular}

a Virulence was not detected for $\operatorname{Rph} 3, \operatorname{Rph} 7, \operatorname{Rph} 11$, or $R p h 14$.

b Not tested.

Table 4. Pathotypes of Puccinia hordei identified from region 1 (northern New South Wales and Queensland) from 1992 to 2001

\begin{tabular}{|c|c|c|c|c|c|c|c|c|c|c|c|}
\hline \multirow[b]{2}{*}{ Pathotype } & \multicolumn{10}{|c|}{ Year } & \multirow[b]{2}{*}{ Total } \\
\hline & 1992 & 1993 & 1994 & 1995 & 1996 & 1997 & 1998 & 1999 & 2000 & 2001 & \\
\hline $200 \mathrm{P}+$ & 0 & 3 & 0 & 0 & 0 & 0 & 0 & 0 & 0 & 0 & 3 \\
\hline $210 \mathrm{P}+$ & 2 & 0 & 0 & 0 & 0 & 0 & 0 & 1 & 0 & 0 & 3 \\
\hline $220 \mathrm{P}+$ & 1 & 0 & 0 & 0 & 0 & 0 & 1 & 0 & 0 & 0 & 2 \\
\hline $230 \mathrm{P}+$ & 0 & 1 & 0 & 0 & 0 & 0 & 0 & 0 & 0 & 0 & 1 \\
\hline 243P- & 1 & 0 & 0 & 0 & 0 & 0 & 0 & 0 & 0 & 0 & 1 \\
\hline $243 \mathrm{P}+$ & 0 & 2 & 0 & 0 & 2 & 0 & 0 & 0 & 0 & 1 & 5 \\
\hline 4610P+ & 0 & 0 & 0 & 0 & 0 & 0 & 0 & 7 & 1 & 5 & 13 \\
\hline $4653 \mathrm{P}+(+R p h 13)$ & 0 & 0 & 0 & 0 & 0 & 0 & 0 & 0 & 1 & 0 & 1 \\
\hline $5610 \mathrm{P}+$ & 0 & 0 & 0 & 0 & 0 & 0 & 0 & 2 & 0 & 2 & 4 \\
\hline No isolates & 4 & 6 & 0 & 0 & 2 & 0 & 1 & 10 & 2 & 8 & 33 \\
\hline No samples & 2 & 3 & 0 & 0 & 2 & 0 & 1 & 8 & 1 & 5 & 22 \\
\hline
\end{tabular}

Table 5. Pathotypes of Puccinia hordei identified from region 2 (southern New South Wales, Victoria, and Tasmania) from 1992 to 2001

\begin{tabular}{|c|c|c|c|c|c|c|c|c|c|c|c|}
\hline \multirow[b]{2}{*}{ Pathotype } & \multicolumn{10}{|c|}{ Year } & \multirow[b]{2}{*}{ Total } \\
\hline & 1992 & 1993 & 1994 & 1995 & 1996 & 1997 & 1998 & 1999 & 2000 & 2001 & \\
\hline $200 \mathrm{P}+$ & 1 & 4 & 0 & 0 & 1 & 0 & 5 & 2 & 0 & 0 & 13 \\
\hline $201 \mathrm{P}+$ & 0 & 0 & 0 & 0 & 0 & 0 & 1 & 0 & 0 & 0 & 1 \\
\hline $210 \mathrm{P}+$ & 0 & 5 & 0 & 1 & 0 & 0 & 1 & 1 & 0 & 0 & 8 \\
\hline $220 \mathrm{P}+$ & 2 & 9 & 0 & 0 & 0 & 1 & 13 & 3 & 0 & 5 & 33 \\
\hline $232 \mathrm{P}+$ & 4 & 3 & 0 & 0 & 0 & 0 & 0 & 0 & 0 & 0 & 7 \\
\hline $242 \mathrm{P}+$ & 0 & 0 & 0 & 0 & 0 & 0 & 1 & 0 & 0 & 0 & 1 \\
\hline $243 \mathrm{P}+$ & 2 & 10 & 0 & 2 & 1 & 0 & 2 & 1 & 0 & 0 & 18 \\
\hline $253 \mathrm{P}+$ & 0 & 1 & 0 & 0 & 0 & 0 & 0 & 0 & 0 & 0 & 1 \\
\hline $272 \mathrm{P}+$ & 0 & 0 & 0 & 0 & 0 & 0 & 0 & 1 & 0 & 0 & 1 \\
\hline $4610 \mathrm{P}+$ & 0 & 10 & 3 & 9 & 5 & 2 & 12 & 8 & 7 & 0 & 56 \\
\hline $4652 \mathrm{P}+(+R p h 13)$ & 0 & 0 & 0 & 0 & 0 & 0 & 0 & 0 & 0 & 1 & 1 \\
\hline $4653 \mathrm{P}+(+R p h 13)$ & 0 & 0 & 0 & 0 & 0 & 0 & 0 & 11 & 7 & 6 & 24 \\
\hline $5452 \mathrm{P}+$ & 0 & 0 & 0 & 0 & 0 & 0 & 0 & 4 & 15 & 24 & 43 \\
\hline $5610 \mathrm{P}+$ & 0 & 0 & 0 & 0 & 0 & 0 & 1 & 11 & 3 & 1 & 16 \\
\hline $5653 \mathrm{P}+$ & 0 & 0 & 0 & 0 & 0 & 0 & 0 & 0 & 0 & 4 & 4 \\
\hline $5673 \mathrm{P}+$ & 0 & 0 & 0 & 0 & 0 & 0 & 0 & 0 & 0 & 4 & 4 \\
\hline No isolates & 9 & 42 & 3 & 12 & 7 & 3 & 36 & 42 & 32 & 45 & 231 \\
\hline No samples & 6 & 21 & 3 & 10 & 6 & 3 & 19 & 24 & 16 & 26 & 134 \\
\hline
\end{tabular}


The origins of the two Rph12 virulent pathotypes first detected in WA, pts $5610 \mathrm{P}+$ and $5453 \mathrm{P}-$, are not clear. The former pathotype, although superficially resembling pt $4610 \mathrm{P}+$, was shown to differ from this pathotype in possessing virulence for $R p h 10$, virulence for the barley line PI366444, and avirulence for an uncharacterized gene in Gatami (Table 1). It is also unlikely that these two pathotypes are closely related because $\mathrm{pt}$ $4610 \mathrm{P}+$ has not been recorded from WA. $\mathrm{Pt} 5453 \mathrm{P}$ - differed from $5610 \mathrm{P}+$ in at least seven pathogenic traits: virulences for Rph1, Rph2, and RphGatami; avirulences for Rph8, Rph19, and RphCantala; and a strong flecking infection type $(;++\mathrm{N})$ on Cebada Capa (Table 1). The latter trait was also produced when a near isogenic line of Bowman with the resistance gene $R p h 7$ was used, and has not been seen with any other Australian isolate of P. hordei (R. F. Park, unpublished data).

The remaining five pathotypes virulent for Rph12 (4652P+ [+Rph13], 4653P+ [+Rph13], 5452P+, 5653P+, and 5673P+) were all pathogenically different from the first Rph12 virulent pathotype detected, pt $4610 \mathrm{P}+$. While it is possible that $\mathrm{pt}$ $4653 \mathrm{P}+(+R p h 13)$ could be a mutational derivative of pt $4652 \mathrm{P}+(+R p h 13)$ with added virulence for $R p h l$, the other pathotypes do not appear to be simple mutational derivatives of existing pathotypes.

\section{DISCUSSION}

Pathogenicity surveys of $P$. hordei during 1992 to 2001 revealed a significant shift in the pathotypic composition of populations across Australia, with virulence for the resistance gene $R p h 12$, first detected in pathotype $4610 \mathrm{P}+$ in Tasmania in 1991, subsequently detected in all states. By 2001, eight pathotypes with virulence for Rph12 had been detected (4610P+, $4652 \mathrm{P}+\quad[+R p h 13], \quad 4653 \mathrm{P}+\quad[+R p h 13]$, $5452 \mathrm{P}+, 5453 \mathrm{P}-, 5610 \mathrm{P}+, 5653 \mathrm{P}+$, and $5673 \mathrm{P}+$ ), all of which were also virulent for Rph4 and Rph9. Virulence was not detected for the resistance genes $R p h 3$, Rph7, Rph11, or Rph14.

In 2001, the proportion of isolates virulent for Rph12 ranged from $62 \%$ in region 3 to $100 \%$ in region 4 . The increase in virulence for Rph12 observed from 1992 to 2001 is most likely the consequence of the release and cultivation of barley cultivars with this resistance gene. The first Australian barley cultivar with Rph12 was Franklin, released in 1989 and initially cultivated in Tas and later in several mainland states including SA and Vic. The cultivars Tallon, Lindwall, Fitzgerald, and Gairdner are also believed to possess Rph12 (R. F. Park, unpublished data). Tallon and Lindwall were released in region 1 in 1991 and 1997, respectively, and have occupied a significant proportion of the area sown to barley in that region in recent years. Similarly, Fitzgerald and Gairdner were released in region 4 in 1997 and were grown not only in that region, but also in some parts of eastern Australia. Several older Australian barley cultivars are believed to carry the resistance gene Rph19 (e.g., Prior, Ketch, Cutter) and the uncharacterized resistance gene RphCantala (e.g., Cantala, Research, Resibee) (R. F. Park, unpublished), and the widespread virulence for both genes detected between 1992 and 2001 could reflect selection pressure following the earlier deployment of cultivars with these genes. The rapid increase of Rph12 virulence in all regions during 1992 to 2001 demonstrates clearly how quickly pathogen populations can adjust to the selective force of host populations.

Ongoing surveys of the pathogenicity of $P$. graminis $\mathrm{f}$. sp. tritici and of $P$. triticina in Australia have provided clear evidence of migration among all cereal growing regions, with periodic movement of isolates from west to east on prevailing winds (8). The results presented here strongly implicate migration of $\mathrm{pt} 4610 \mathrm{P}+$, either from Tas to SA or from SA to Tas (3), and subsequently to Vic, NSW, and Qld. The detection of pt 5610P+ in WA in 1997, followed by its detection in SA and Vic in 1998 and in NSW and Qld in 1999, further demonstrates the widespread movement of rust inocula within Australia, including exchange between the western and eastern cereal growing regions. Other examples of inoculum exchange between the western and eastern cereal growing regions include pathotypes of $P$. graminis f. sp. tritici (8)

Table 6. Pathotypes of Puccinia hordei identified from region 3 (South Australia) from 1992 to 2001

\begin{tabular}{|c|c|c|c|c|c|c|c|c|c|c|c|}
\hline \multirow[b]{2}{*}{ Pathotype } & \multicolumn{10}{|c|}{ Year } & \multirow[b]{2}{*}{ Tota } \\
\hline & 1992 & 1993 & 1994 & 1995 & 1996 & 1997 & 1998 & 1999 & 2000 & 2001 & \\
\hline $200 \mathrm{P}+$ & 0 & 3 & 2 & 0 & 2 & 0 & 0 & 0 & 0 & 0 & 7 \\
\hline $210 \mathrm{P}+$ & 0 & 7 & 1 & 0 & 1 & 0 & 0 & 0 & 0 & 1 & 10 \\
\hline $211 \mathrm{P}+$ & 0 & 1 & 1 & 0 & 0 & 0 & 0 & 0 & 0 & 0 & 2 \\
\hline $220 \mathrm{P}+$ & 0 & 1 & 1 & 0 & 8 & 0 & 6 & 2 & 7 & 3 & 28 \\
\hline $222 \mathrm{P}+$ & 0 & 0 & 0 & 0 & 0 & 0 & 1 & 0 & 2 & 1 & 4 \\
\hline $230 \mathrm{P}+$ & 1 & 4 & 0 & 0 & 0 & 0 & 0 & 0 & 0 & 0 & 5 \\
\hline $232 \mathrm{P}+$ & 2 & 7 & 0 & 0 & 1 & 0 & 0 & 0 & 0 & 0 & 10 \\
\hline $243 \mathrm{P}+$ & 1 & 4 & 0 & 0 & 2 & 0 & 0 & 0 & 0 & 0 & 7 \\
\hline $253 \mathrm{P}+$ & 0 & 1 & 0 & 0 & 0 & 0 & 0 & 0 & 0 & 0 & 1 \\
\hline $262 \mathrm{P}+$ & 0 & 0 & 1 & 0 & 0 & 0 & 0 & 0 & 0 & 0 & 1 \\
\hline $272 \mathrm{P}+$ & 0 & 0 & 1 & 0 & 0 & 0 & 0 & 0 & 0 & 0 & 1 \\
\hline $4610 \mathrm{P}+$ & 0 & 7 & 1 & 0 & 6 & 1 & 4 & 1 & 5 & 2 & 27 \\
\hline $4653 \mathrm{P}+(+R p h 13)$ & 0 & 0 & 0 & 0 & 0 & 0 & 0 & 0 & 1 & 1 & 2 \\
\hline $5452 \mathrm{P}+$ & 0 & 0 & 0 & 0 & 0 & 0 & 0 & 2 & 8 & 5 & 15 \\
\hline $5610 \mathrm{P}+$ & 0 & 0 & 0 & 0 & 0 & 0 & 1 & 3 & 3 & 0 & 7 \\
\hline No isolates & 4 & 35 & 8 & 0 & 20 & 1 & 12 & 8 & 26 & 13 & 127 \\
\hline No samples & 3 & 19 & 3 & 0 & 11 & 1 & 7 & 4 & 12 & 5 & 65 \\
\hline
\end{tabular}

Table 7. Pathotypes of Puccinia hordei identified from region 4 (Western Australia) from 1992 to 2001

\begin{tabular}{|c|c|c|c|c|c|c|c|c|c|c|c|}
\hline \multirow[b]{2}{*}{ Pathotype } & \multicolumn{10}{|c|}{ Year } & \multirow[b]{2}{*}{ Total } \\
\hline & 1992 & 1993 & 1994 & 1995 & 1996 & 1997 & 1998 & 1999 & 2000 & 2001 & \\
\hline $200 \mathrm{P}+$ & 0 & 1 & 0 & 0 & 0 & 0 & 0 & 0 & 0 & 0 & 1 \\
\hline $220 \mathrm{P}+$ & 0 & 1 & 0 & 0 & 0 & 0 & 0 & 0 & 0 & 0 & 1 \\
\hline $243 \mathrm{P}+$ & 0 & 1 & 0 & 0 & 0 & 0 & 0 & 0 & 0 & 0 & 1 \\
\hline 5453P- & 0 & 0 & 0 & 0 & 0 & 0 & 0 & 0 & 0 & 9 & 9 \\
\hline $5610 \mathrm{P}+$ & 0 & 0 & 0 & 0 & 0 & 2 & 8 & 16 & 1 & 2 & 29 \\
\hline No isolates & 0 & 3 & 0 & 0 & 0 & 2 & 8 & 16 & 1 & 11 & 41 \\
\hline No samples & 0 & 2 & 0 & 0 & 0 & 2 & 8 & 16 & 1 & 10 & 39 \\
\hline
\end{tabular}


and $P$. triticina (12). These observations stress the importance of maintaining a national strategy in breeding cereals for resistance to rusts.

Surveys of the rust pathogens of wheat have also provided strong evidence that new pathotypes are derived by either mutation, or less frequently, exotic introduction or somatic hybridization $(9,11,18,20)$. Presumed clonal lineages have been identified for many of the cereal rust pathogens that comprise closely related pathotypes derived by sequential single-step mutations from a common ancestor (20). In contrast to this, the origins of most pathotypes virulent for Rph12 detected in Australia during 1992 to 2001 are unclear. Detailed comparative tests of these pathotypes demonstrated considerable variability among most of them, and with the possible exceptions of pathotypes 4610P+ and 4653P+ $(+R p h 13)$, which may have developed by mutation from pathotypes $210 \mathrm{P}+$ and $4652 \mathrm{P}+(+R p h 13)$, respectively, it appears unlikely that most arose by simple mutation. P. hordei is the only cereal rust pathogen known to undergo sexual recombination in Australia. The alternate host, Ornithogalum umbellatum, is known to generate new virulence combinations and is significant in the initiation of leaf rust epidemics in SA, where it is largely confined to parts of the Yorke Peninsula (16; Fig. 1). All of the Rph12 virulent pathotypes first detected in eastern Australia were isolated initially from either Tas (4610P+, 4653P+, 5673P+, and 4652P+), Vic $(5653 \mathrm{P}+)$, or SA $(5452 \mathrm{P}+)$; and in view of the free movement of inoculum among these regions, it is possible that all originated from $O$. umbellatum in SA. Alternatively, $O$. umbellatum may occur more widely than is currently thought, or some or all of the new pathotypes may have originated outside Australia. Exotic introductions of cereal rust pathogens have occurred periodically, often with profound effects on local populations. Although the origins of these exotic isolates are in most cases not known, there is good evidence that three pathotypes of $P$. graminis $\mathrm{f}$. $\mathrm{sp}$. tritici originated from Africa (pt 21-0 in 1954 [7]; pts 194-1,2,3,5,6 and 326$1,2,3,5,6$ in 1969 [19]), and two pathotypes of $P$. triticina originated from New Zealand (pt 53-1,(6),(7),10,11, 1984 [9]; pt 761,3,5,10, 1998 [R. F. Park, unpublished data]). The pathotypes of $P$. hordei detected in Australia are distinct from the two pathotypes detected from 1994 to 1999 in South Africa (15). Two pathotypes, $4653 \mathrm{P}+(+$ Rph13 $)$ and 5673P+, are very similar to two pathotypes (pts 4653 and 4673 , respectively) detected in New Zea- land from 1990 to 1993 (4). Differentials with the resistance genes Rph10, Rph11, $R p h 13$, and $R p h 19$ were not used to characterize isolates in New Zealand, and additional comparative tests utilizing these differential genotypes could provide further evidence of their similarity to the isolates detected in Australia.

The rapid development of virulence for Rph12 in all barley growing regions of Australia between 1992 and 2001 demonstrates the importance of avoiding overreliance on single gene resistances. The effectiveness of Rph3, Rph7, Rph11, and $R p h 14$ means they could be useful sources of resistance to $P$. hordei; however, incorporation of these genes singly, particularly in susceptible backgrounds, is undesirable. Observations in New Zealand, where virulence for Rph 3 developed following the release of the cultivar Liberty, believed to carry this resistance gene (4), further highlight the vulnerability of single gene resistances. Other promising sources of seedling resistance that have been tested against Australian isolates of $P$. hordei include $R p h 15$ and $R p h 18$ (R. F. Park, unpublished data). Selecting combinations involving the genes $R p h 3, R p h 7, R p h 15$, and Rph18 will not be possible using simple greenhouse tests, because cultures virulent on the individual genes are not available in Australia, and all four genes confer very low infection types. Linked molecular markers would therefore be of great value. Partial or slow rusting resistances are also known to confer adequate levels of resistance to $P$. hordei. Several European barley cultivars with reputed slow rusting performed satisfactorily under conditions in Qld (2). One of these cultivars, Koru, was reselected under local conditions and released as cultivar Gilbert, a cultivar that is seedling susceptible to $P$. horde $i$ but has adequate levels of resistance at adult plant growth stages.

\section{ACKNOWLEDGMENTS}

This work was conducted with the financial support of the Grains Research and Development Corporation Australia. The technical assistance of Ms. L. Ferrari and Mr. M. J. Williams is gratefully acknowledged.

\section{LITERATURE CITED}

1. Cotterill, P. J., Park, R. F., and Rees, R. G. 1995. Pathogenic specialisation of Puccinia hordei Otth. in Australia, 1966 - 1990. Aust. J. Agric. Res. 46:127-134.

2. Cotterill, P. J., and Rees, R. G. 1993. Evaluation of European "slow-rusting" barleys in Queensland. Trends Agrochem. Cultivars 14:166-167.

3. Cotterill, P. J., Rees, R. G., and Vertigan, W. A. 1991. Detection of Puccinia hordei virulent on the $P a 9$ and Triumph resistance genes in barley in Australia. Aust. Plant Pathol. 21:32-34.
4. Cromey, M. G., and Villjanen-Rollinson, S. L. H. 1995. Virulence of Puccinia hordei on barley in New Zealand from 1990 to 1993. N.Z. J. Crop Hortic. Sci. 23:115-119.

5. Dill-Macky, R., Rees, R. G., Johnston, R. P., Platz, G. J., and Mayne, A. 1989. Stem and leaf rusts of barley. Pages 38-40 in: Queensland Wheat Research Institute Biennial Report 1984-1986. Queensland Department of Primary Industries, Toowoomba, Australia.

6. Jones, E. R. L., and Clifford, B. C. 1985. Brown rust of barley. United Kingdom Cereal Pathogen Virulence Survey. 1984 Annu. Rep. pp. 58-62.

7. Luig, N. H. 1977. The establishment and success of exotic strains of Puccinia graminis tritici in Australia. Proc. Ecol. Soc. Aust. 10:89-96.

8. Luig, N. H. 1985. Epidemiology in Australia and New Zealand. Pages 301-328 in: The Cereal Rusts. Vol. II, Diseases, Distribution, Epidemiology, and Control. A. P. Roelfs and W. R. Bushnell, eds. Academic Press Inc., Orlando, FL.

9. Luig, N. H., Burdon, J. J., and Hawthorn, W. M. 1985. An exotic strain of Puccinia recondita tritici in New Zealand. Can. J. Plant Pathol. 7:173-176.

10. McIntosh, R. A., Wellings, C. R., and Park, R. F. 1995. Wheat Rusts. An Atlas of Resistance Genes. CSIRO, Melbourne, Australia.

11. Park, R. F., Burdon, J. J., and Jahoor, A. 1999. Evidence for somatic hybridisation in the leaf rust pathogen of wheat (Puccinia recondita $\mathrm{f}$. sp. tritici). Mycol. Res. 103:715-723.

12. Park, R. F., Burdon, J. J., and McIntosh, R. A 1995. Studies on the origin, spread, and evolution of an important group of Puccinia recondita f. sp. tritici pathotypes in Australasia. Eur. J. Plant Pathol. 101:613-622.

13. Park, R. F., and Karakousis, A. 2002. Characterisation and mapping of gene Rph19 conferring resistance to Puccinia hordei in the cultivar Reka 1 and several Australian barleys. Plant Breed. 121:232-236.

14. Stakman, E. C., and Piemeisel, F. J. 1917. Biologic forms of Puccinia graminis on cereals and grasses. J. Agric. Res. 10:429-495.

15. van Niekerk, B. D., Pretorius, Z. A., and Boshoff, W. H. P. 2001. Occurrence and pathogenicity of Puccinia hordei on barley in South Africa. Plant Dis. 85:713-717.

16. Wallwork, H., Preece, P., and Cotterill, P. J. 1992. Puccinia hordei on barley and Ornithogalum umbellatum in South Australia. Aust. Plant Pathol. 21:95-97.

17. Waterhouse, W. L. 1927. Studies in the inheritance of resistance to leaf rust, Puccinia anomola Rostr., in crosses of barley. I. J. Royal Soc. N.S.W. 61:218-247.

18. Watson, I. A. 1981. Wheat and its rust parasites in Australia. Pages 129-147 in: Wheat Science - Today and Tomorrow. L. T. Evans and W. J. Peacock, eds. Cambridge University Press, Cambridge, UK.

19. Watson, I. A., and de Sousa, C. N. A. 1983. Long distance transport of spores of Puccinia graminis tritici in the southern hemisphere. Proc. Linn. Soc. N.S.W. 106:311-321.

20. Wellings, C. R., and McIntosh, R. A. 1990 Puccinia striiformis f.sp. tritici in Australasia: Pathogenic changes during the first 10 years. Plant Pathol. 39:316-325.

21. Zwer, P. K., Park, R. F., and McIntosh, R. A. 1992. Wheat stem rust in Australia 1969 1985. Aust. J. Agric. Res. 43:399-431. 